\title{
Tax Advisors and Professional Secrecy in Directive 2011/16/EU of the Council of February 15, 2011
}

\section{Medina Suarez F*}

PhD in Law, Publications Advisory Council (Associate Editors), Spain

*Corresponding author: Francisco Medina Suarez, PhD in Law, Publications Advisory Council (Associate Editors), Gran Canaria, Spain, Email: info@medinasuarez.es

\section{Conceptual Paper}

Volume 4 Issue 4

Received Date: September 13, 2021

Published Date: October 01, 2021

DOI: $10.23880 /$ abca- 16000202

\section{Abstract}

This article makes a modest and succinct exposition over the situation of tax advisers with the tax administration and their clients in the European Union, referring to professional secrecy as an essential basis of trust with their clients within the content of DIRECTIVE (EU) 2018/822 OF THE COUNCIL, of May 25, 2018 that modifies Directive 2011/16/EU, on administrative cooperation in the field of taxation and repealing Directive 77/799/EEC.

Keywords: Automatic Exchange of Information; Council Directive 2011/16/EU; Reciprocal Administrative Assistance; Administrative Cooperation; Professional Secrecy; European Union

\section{Introduction}

The growing internationalization of the economy is not a recent event. It dates back to several decades. Its importance and impact was reflected in the 1963 Model Convention of the OECD (MCOCDE) and even in the post-war periods [1]. Information exchange clauses had been inserted in the MCOCDE in order to have the necessary resources to verify correct compliance with tax obligations by taxpayers in the signatory jurisdictions.

Within the European Union, the increase in investment and cross-border expansion of economic activities has led the approval of successive Community rules for the exchange of information. The latest was COUNCIL DIRECTIVE 2011/16/ EU of 15 February 2011 on administrative cooperation in the field of taxation and repealing Directive 77/799/EEC [2]. This rule was based over the urgent need for mutual assistance between the Member States through the automatic exchange of efficient information to combat tax fraud, by the increasing globalization of the internal market ${ }^{1}$, as well as the deficiencies presented by Directive 77/799/CEE that repealed the new norm. Directive 2011/16/EU approach direct and indirect taxes not yet covered by Union legislation

$\overline{1}$ Texts in italics cite literal content. by enhancing and stimulating the spontaneous exchange of information between EU Member States.

\section{Objective and Instruments of Council} Directive 2011/16/EU of 15 February 2011 on Administrative Cooperation in the field of Taxation and Repealing Directive $77 / 799 / \mathrm{EEC}$

Without intending to approach here a profuse study of the content of Directive 2011/16/EU or to deviate the object of this article, it is opportune to set out the essential mechanisms provided by this rule, which will allow us to assess the suitability and proportionality of the obligations imposed on tax advisers in the modification of this rule by COUNCIL DIRECTIVE (EU) 2018/822 of 25 May 2018 amending Directive 2011/16/EU as regards mandatory automatic exchange of information in the field of taxation in relation to reportable cross-border arrangements [3].

The essential objective of this rule is to establish effective administrative cooperation between Member States in order to overcome the negative effects of increasing globalization on the internal market which cannot be sufficiently achieved by 
Member States and therefore due to the required consistency and efficiency can best be achieved at Union level.

Over the resources contained in this law for the achievement of its objectives, it should be noted that the scope of the standard includes all taxes of the member states and their territorial or administrative divisions, excluding social security contributions, VAT, tariffs and special taxes provided in other European Union regulations on administrative cooperation (Article 2). Although, within the taxes included in the ambit of application, it only affects dependent work income, director's fees, life insurance products (not covered by other legal instruments of the Union, on the exchange of information and other similar measures) pensions and ownership of real estate and real estate income (article 8.1). The exchange of information is carried out upon request (Article 5) that may be denied with justification by the other State (Article 6); and also if this implies the disclosure of commercial, industrial or professional secrets, commercial procedure or information contrary to the public interest (Article 17). States may also spontaneously exchange information, on their own initiative, if they have reasons to presume its relevance (Article 9). Likewise, investigation work may be carried out in the offices of the administrations of other member states with the scope and requirements set forth in article 11. Similarly, simultaneous controls of the information are foreseen when there are two or more countries interested in the investigation. (Article 12), as well as requesting return information for the countries that sent it over the result (Article 14). The information provided may also be used to assess and apply other taxes and duties provided in article 2 of Council Directive 2010/24/EU, of March 16, 2010, on mutual assistance in the collection of credits corresponding to certain taxes, duties and other measures, or to evaluate and execute mandatory contributions in the field of social security (Article 16). However, the State from which the information comes may oppose it (article 8.3). Finally, Directive 2011/16/EU includes a set of minimum rules, but European countries may increase the cooperation between them, in accordance with their national law, bilateral or multilateral agreements that may expand the framework of action provided in the European law.

Council Directive (EU) 2018/822 of 25 May 2018 Amending Directive 2011/16/EU as regards Mandatory Automatic Exchange of Information in the Field of Taxation in Relation to Reportable Cross-Border Arrangements

The instruments regulated in Directive 2011/16/EU contain a wide range of options for collecting information (in addition to those provided in double taxation conventions or other international treaties). However, it doesn't seem to be sufficient to achieve the objectives enshrined in it. For this reason, the preamble of Directive 2018/822/EU sets out that the European Parliament has required stricter mechanisms against intermediaries (essentially, tax advisory professionals) who provide help for tax avoidance and evasion, in addition to the need to combat the legal channels that circumvent the communication of information exposed in the G7 Declaration of Bari, of May 13, 2017. In this context, it is affirmed that some intermediaries and tax advisers have actively collaborated to hide money from clients in foreign jurisdictions. Although the percentage of cases is not reported, at least an approximate one, that justifies the scope of the measures contained in Directive 2018/822/ EU [4], regarding intermediaries and tax advisers. In line with all this, the preamble to the regulation justifies the obligation to communicate information to professionals who participate in the conception, commercialization, planning or management of cross-border economic operations ${ }^{2}$, amen to the cases in which it concerns to the taxpayer, when they operate without professional assistance. And it insists on the need for Member States to provide proportionate and persuasive sanctions for compliance with the rule.

Despite the notorious repercussions arising from these measures imposed on tax advisers, the rule attempts to provide an appearance of proportionality by outlining the necessary synchronization between the automatic exchange of information, the obligation of communication by professionals and international developments, adding distinctive signs in Annex IV over the mechanisms involving cross-border transactions, which must be subject to communication of information.

\section{The Professional Secrecy of Tax Advisers in Directive (EU) 2018/822}

The disclosure of confidential information revealed by the client to the professional constitutes a flagrant breach of the duty of professional secrecy. In fact, in the Sentence of the Court of Justice of the European Union (Grand Chamber), of September 14, 2010, case C-550/07PI-8360 [5], it argued that "the confidentiality of communications between lawyers and their clients should be object of protection at the community level" conditioning it to fulfill two requirements:

- Relationship between client and independent lawyer;

- The correspondence must refer to the exercise of the

\footnotetext{
2 Definition is introduced in the modification of article 3, paragraph 21; the scope of application and conditions are determined in article 8 bister, and the guidelines for the duty of information are established by means of the distinctive signs in annex IV.
} 


\section{client's defense rights ${ }^{3}$.}

In the same resolution, section 21 of the AM \& S / Commission judgment was cited, where the European Court emphasized that within the framework of European Community Law, "the principles and concepts common to the Rights of the Member States regarding respect for confidentiality, especially as regards communication between lawyers and their clients (see paragraph 18 of that judgment). To this end, the Court of Justice carried out a comparison of the different national legal systems". In this order, professional secrecy is also protected by Article 8 of the European Convention on Human Rights (an integral part of the acquis communautaire) as a fundamental element of trust between the lawyer (or tax advisor) and the client [6].

We must clarify that, in any moment, we postulate the violation of professional secrecy in cases in which public order is disturbed (for example, money laundering, terrorism or flagrant crime), in accordance with the Sentence of the Court of Justice of the Union European (Grand Chamber), of September 13, 2018, case C-358/16 [7], in which fences the dispensation of professional secrecy in the cases provided for in the Criminal Code. On the contrary, in some of the distinctive features of Annex IV introduced in Directive 2018/822/EU, we could consider the dichotomy between the commission of a crime that justifies dispensing with the duty of confidentiality and obtaining a legal tax benefit operating in another European jurisdiction, at the time of the legitimate exercise of the fundamental freedoms that cement the European internal market, namely, free movement of capital and freedom of establishment.

For example, in Part II, A.2.a) of Annex IV, a distinctive sign is considered that generates the obligation to communicate the agreement to receive fees from the tax advisor, based on the amount of the tax benefit obtained. Here, we must ask ourselves, whether advising the client by recommending the best tax jurisdiction in a democratic European State (with legal tax benefits), part of the European internal market, creates a disturbance of public order that triggers infringement of professional secrecy. In my modest point of view, it cannot be presented as a suitable assumption to infringe an essential right such as professional secrecy. Especially when it is public and notorious that investment and relocation business decisions are not limited exclusively for tax reasons. There are also other factors of extraordinary importance such as labor costs, legal-labor flexibility, market, bureaucracy, prestige of the institutions, security legal, etc., while tax costs are part of the structure of the business to be designed.

3 Excluding relationships between client and lawyer through legal employment relationship.
We must add that the preamble of Directive 2018/822/ EU points out the need to prevent that professionals break their duty of secrecy, which justifies that the taxpayer must inform the administration in cases of aggressive tax planning. However, the assumption outlined in the previous paragraph cannot be considered as aggressive tax planning due to the fact that the fees of a professional are determined based on the choice of the best tax regime (together with other factors provided by other professionals such as consultants company), if it is a weighted decision with a view to obtaining a legal tax benefit within the context of the European internal market. Then we could ask ourselves where the turning point is to diminish, even partially, the duty of professional secrecy in the case raised.

Over all of the above, it should be added that competitiveness in the European internal market is not only the task of companies but also of countries carrying out a weighted tax competition policy to attract capital, in addition to other important factors that generate confidence in investors. In my humble opinion, it is very likely that not all European Union countries have had the same interest in this rule goes far. This could be the case of jurisdictions such as Luxembourg, Hungary, Ireland, Malta or Cyprus, among others, which have the most attractive corporate taxes in the European internal market ${ }^{4}$.

\section{Conclusions}

The assumptions contained in Annex IV and the reporting obligations by tax advisers in Directive 2018/822/EU must be interpreted in a restrictive sense in order to safeguard professional secrecy. At the same time, these professionals require a reasonable margin of interpretation in complying with the assumptions of the obligation to communicate.

Directive 2011/16/EU provides a minimum content that can be extended by the Member States. However, this extension will require a rigorous audit by the competent bodies of the European Union to prevent in some countries going from the "justified infringement" of professional secrecy to the conversion of tax advisers into full confidants of the administration tributary.

The assumption contemplated in Part II, A.2.a) of annex IV, is not suitable to oblige the tax advisor to violate professional secrecy within the context of the internal market in which it intervenes. It has not been possible to verify a justifying

\footnotetext{
4 Luxembourg has an exemption on the repatriation of dividends, interest and capital gains, in addition to a maximum rate of $17 \%$. Hungary taxes corporate profits at 9\%; Ireland and Cyprus at 12.5\%. Malta regulates a Holding regime that, after subjecting $35 \%$ to a levy, gives a discount and returns $30 \%$. This information can be consulted on the web https:// santandertrade.com/es locating the specific information for each country.
} 
study of the percentage of assumptions of collaboration by tax advisers with their clients that allows concluding the need for this invasion of confidentiality measures.

Tax competition, the adequate allocation of public resources and the suitability of legal systems that avoidance bureaucracies, lack of legal certainty, excessive labor costs, transparency, etc., would contribute to improving the fight against tax evasion and fraud to the detriment of obese state structures.

\section{References}

1. (2017) Model Tax Agreement on Income and on Assets, abridged version, Madrid. Institute of Fiscal Studies, UK.

2. (2011) Council Directive $2011 / 16 / \mathrm{EU}$, on administrative cooperation in the field of taxation and repealing Directive 77/799/EEC (Official Journal of the European Union, 11.3.2011, L 64/1-12).
3. (2018) Council Directive (EU) 2018/822, amending Directive 2011/16/EU as regards mandatory automatic exchange of information in the field of taxation in relation to reportable cross-border arrangements (Official Journal of the European Union,5.6.2018, L 139/1-13).

4. (2014) Council Directive 2014/107/EU, amending Directive 2011/16/EU as regards mandatory automatic exchange of information in the field of taxation (Official Journal of the European Union, 16.12.2014, L 359/1-29).

5. (2010) Sentence of the Court of Justice of the European Union (Grand Chamber), case C-550/07PI-8360.

6. (2012) Sentence of the European Court of Human Rights, case Michaud v. France.

7. (2018) Sentence of the Court of Justice of the European Union (Grand Chamber), case C-358/16. 